\title{
Discussion on Teaching Reform of Financial Management Based on Practical Ability Training
}

\author{
Jie $X u^{1, a}$ \\ ${ }^{1}$ Business School, Qilu University of Technology, Jinan250353, China \\ aemail:xujietimes@163.com
}

Keywords: Financial management teaching, Teaching method, Practice ability.

\begin{abstract}
Financial management of practical teaching is advantageous to the close combination of financial management theory and practice. The paper aims at the current problems in practical abilities training in college financial management teaching and proposes several advices. In the teaching reform, the teacher can use some teaching methods such as heuristic teaching, case teaching and the "sandbox" teaching in line with the teaching content. While the colleague should strengthen the management of students practice training, so as to improve students ' practical ability to analyze and solve the problem.
\end{abstract}

\section{Introduction}

Financial management is a core university curriculum in accounting majors, but also a main course in finance and management majors; it occupies an important position in the business management disciplines. While financial management is a highly practical and hands-on course. Graduates who major in financial management can apply the theoretical knowledge to practical work when he is at work in enterprises and institutions. Therefore, most employers require candidates to have some practical ability and experience, and this is precisely what many university graduates lack.

As to meet the need of the job market for graduates practice ability, teachers should shift the teaching concept, change the status quo in the teaching of financial management course which traditional education too much emphasis on theoretical teaching, theory divorced from reality, and classroom teaching are always around textbook as Center. Meanwhile, teachers should take the practice teaching as an important part of financial management teaching, complement and extend the theoretical teaching, cultivate students' practical ability; exposing students to practical problems will no longer be in helpless predicament.

\section{Problems in the course of financial management teaching}

The teaching patterns is not scientific

It is a strong practical and applied course of financial management, but at present, the teaching concepts and thoughts in college have not been really departure from traditional teaching pattern with "teacher-centered". That is dominant with teachers' teaching, centering on the teaching material, teachers' roles are imparting theoretical knowledge, through teaching feeding complete and systematic theory knowledge to students. This model can help students build a solid theoretical foundation and complete knowledge system, but there are also shortcomings can not be avoided. Whether in the form of blackboard writing or PPT, it is not really a breakthrough of the traditional pattern of teacher force-feeding model and lack of interaction between teachers and students. So it is difficult to give students enough time to think independently, to mobilize students' learning enthusiasm and initiative.

In addition, the "teacher centered" teaching mode ignore the importance of practical teaching, although simulated practice will be conduct but usually after completing their studies in theoretical courses, so that the students can't get perceptual knowledge in theory study. Because of the limited conditions and the lack of experienced teachers in most universities simulated practice hard to do real simulations. 
The divergence of the teaching content and Practice

At present, various versions of university financial management teaching content basically revolves around the capital market, mainly to solve company's problems in the capital market financing, investment, capital operation and the assignment. There is no doubt about the integrity and systematic of the theory, but it deviates from practice is more obvious:

I . Many theories and decision-making method in financial management aimed at listed corporation, for the vast majority of non-listed companies it has weak adaptability. For college graduates, only the few are luckily to go to listed companies.

II .At present domestic textbooks are basically adopts the western financial management theory, but there are many different financing environment and the practice between the western and Chinese, leading to gaps in financial management of the teaching content and practice. It also makes graduates feel the knowledge what they have learned not much use in practice.

III. In financial management, value standard is the sole criterion for decision-making, ignores the non value indicators, such as social responsibility. In the standard of value, with particular emphasis on maximizing the value of the company or shareholder value, ignoring the social value outside the company. But in real life, social responsibility and impact on social value are important parts of the enterprise mission, are also factors that cannot be ignored in the financial management decisions. In addition, the financial management decision relies on the quantitative factors, failed to consider the unquantifiable factors such as company culture, System.

Failings to cultivate students ' initiatives, practical skills and problem solving ability

As the theoretical course content disengages practice, When the teacher transfer the theorized knowledge, students show little interests in the pure theoretical sermon, learning is more for exams and get credit 。 It can't mobilize students' interest in learning from the practical application level and has adverse effect on the cultivation of learning enthusiasm and the initiative.

In addition, in the course of practice, most of the content is still confined to the calculation and problem solving, always focus on theory, and practice is not enough, which led to student's practical ability and problem-solving ability is weak. Once encounter practical problems to solve, students will be at a loss what to do.

\section{Thinking of teaching reform of financial management based on practical ability training}

Under the new economic and educational environment, teachers must change teaching ideas, use the advanced teaching means, constantly explore new teaching methods in teaching of financial management, they are committed to fostering students ' creativity and practical ability.

Changing traditional teaching patterns, re-orientation of teacher's role

"Teacher-centered" teaching model fail to achieve a better integration of theory and practice. To change this pattern, we must gradually establish the heuristic teaching mode, and the role of teacher from changing theoretical knowledge into students' learning guide.

In heuristic teaching model, teachers can inspire students to think about fully, guide and coach them step by step, finally solve the problem satisfactorily ${ }^{[1]}$. In this way students can change the habit of passive learning to actively participate in the process of knowledge transfer, that make learning becomes active knowledge acquisition process.

The core of heuristic teaching is that teachers should be good at asking questions, guide students to think actively, realize the good interaction between the teachers and students in class, and fully mobilize students' learning enthusiasm, to enable students to develop the habit of positive thinking and speaking. In the long run, thinking ability of the students to analyze and solve problems will be gradually improved.

For example, when explain calculation on the time value of money, the teacher may guide students to thinking after introducing basic theories and methods, discuss each kind of calculation can be applied to any personal financial problems in real life. Students can understand the theory more deeply through heuristic thinking. This process can enhance their thinking and practical problem solving skills, so that they came to realize that books theory and its application in 
practical work and life, to stimulate their interest in learning.

Case teaching method combined with practice

Heuristic teaching cannot do without the case teaching method. Case teaching method is created by Harvard University in the early 20th century; it is a kind of method with the combination of theory and practice and the cultivation of students' practical ability. It revolves around a certain teaching purpose to make the real scenario in practice to be typical processing and form a case for students thinking, analysis and making decision. It can improve students' ability to analyze and solve problems by independent study and discuss each other. ${ }^{[2]}$ In Current financial management teaching, case teaching method has been used by most teachers more or less but due to case selection and problems that exist on teaching methods, case failed to achieve close integration with practice that will be result in little effect on the improvement of students' practical ability

In order to maximize class time, teachers may supply students the corresponding case data and the problems to be resolved before class, so that the students have enough time to think and preparation. Some methods are used in class like Questioning, dialogue and discussion to provide students with ample opportunity to express their opinions, then, gradually guide and inspire students, let them observe as the protagonist financial management environment in the case, so that they learn to analyze problems logically and be able to integrated use the course content to solve practical problems in financial management.

Meanwhile, the case should be selected in line with China's national conditions as possible. Currently finance management case used in the teaching of mainly come from abroad, because of its rich content and mature system, which has a certain reference. But due to subjective and objective factors of enterprises in China and foreign countries are quite different, so case lacks of applicability. And domestic related cases teaching material is relatively lack, teachers make case that also affected by many conditions, it is more difficult to achieve. From the teacher's point of view, they should put more time and energy on the case teaching, strive for more practice opportunities, and expand the attention to practice, accumulate over a long period to collect case teaching materials directly. ${ }^{[3]}$ Resources can also be shared between teachers, and network should be given full play to now days.

Emphasis on offering and guidance for practical courses

The basic guiding ideology of practice teaching should be: practice course content should be combined with theoretical courses contents, emphasis on experiment, and practice training and internship courses of independence, systematic, and integrity; Courses content highlight operability, comprehensive and innovative. Experimental teaching work should be independent and don not generalized into theory teaching. It emphasizes that the practice of financial management will be carried on under the guidance of the theory of financial management, the teaching contents should combine theory with practice, to cultivate the student's comprehensive ability to have found the problem, analyze and solve problems.

Simulation teaching of financial management

Financial management of the simulated teaching is a kind of experiential teaching methods. Ii is a unique intuitive "sand" to simulate the whole process of production and business operation of the enterprise by taking the form of role-playing, simulation, and teachers review. So that students in the virtual market competition environment engaged in a range of financial activities, such as financing, investment and distribution. [4] The "sand" and "sandbox" demonstration teaching method transplanted to the field of practice teaching of financial management, make it play a unique role in the teaching practice. The specific implementation generally includes the following seven steps: the first step is to form the Simulated company, the second step is to hold early financial planning Conference, the third step is to prepare the annual financial budget, the fourth step is to carry out financial activities, the fifth step is to prepare annual financial statements, the sixth step is to hold financial wrap-up session at the end, the seventh step is teachers analysis and comment on the contents of Simulation teaching. ${ }^{[5]}$

Strengthen the management of students' practice

In the process of recognition internship and graduation practice, it is very important to strengthen 
the students' practice management. Teachers should be organized to inspect and guide students during practice internship, and help them to solve the problem during training. On the other hand, Teachers through direct communication and contact with employers understand requirements and suggestions proposed by employers about the weakness of financial management education found in students post practice. Meanwhile, timely access to student internships feedback is an important way to promote the practice teaching. "Graduation practice communication" should be held at the end of the graduation practice every year, teachers and students are invited to take part in and students talk about feelings and experience get in the practice, as well as feedback from employers regarding the requirements of professional personnel training in financial management. Through this activity, It strengthen the construction of curriculum, make financial management professional teaching can better meet the needs of all aspects.

In addition to the campus practical teaching, off-campus practice is the most direct means to improve students' practical ability and professional level. Colleges and universities should establish extensive contact with enterprise, realizes the university-enterprise cooperation, to establish a stable off-campus practice base, make up for the inadequacy of intramural practical teaching simulation.

Through the internships such as post practice and help post internships in Outside-school practice bases, students in real-world work experience have a more intuitive understanding about professional and their own ability, establish a good foundation for further professional study, but also cultivate the practice skills necessary for practical work after graduation.

\section{Summary}

The reform of the financial management of teaching is to improve teaching quality of financial management discipline, also is requirement the person who is high-quality and innovative. Therefore, the reform of financial management teaching is imperative.

\section{References}

[1] Yinghua Ma, Teaching reform of financial management adapt to the cultivation of innovation ability, Friends of Accounting (Under the ten-day), 2009(6):66- 67.

[2] Yinbo Feng, Thoughts on Financial Management Teaching Methods Case, Value Engineering, 2010(36):283- 284.

[3] Surong Liu, Discussion on financial management teaching reform based on cultivating the applied talents, China Management Informationization, 2008(19):106-108.

[4] Weijun Zeng, Discussion on financial management teaching reform based on cultivating the applied talents target, Journal of Higher Education, 2009(01):58-60.

[5] Huahong Yan, Rui Zhang, Application of ERP sand table simulation teaching in the teaching mode reform of financial management, Finance and accounting, 2013(02):32-35. 